УДК 811.161.2’243

DOI 10.11603/m.2414-5998.2021.4.12698

\author{
О. І. Новіцька \\ ORCID https://orcid.org/0000-0001-5630-6963 \\ С. I. Гнатишин \\ ORCID https://orcid.org/0000-0003-0021-0879
}

Тернопільський національний медичний університет імені І. Я. Горбачевського МОЗ Украӥни

\title{
ВИВЧЕННЯ ТЕМИ «ЛЮДИ І РЕЧІ НАВКОЛО НАС» НА ЗАНЯТТЯХ 3 УКРАЇНСЬКОЇ МОВИ ЯК ІНОЗЕМНОЇ: МЕТОДИЧНА РОЗРОБКА ДЛЯ ВИКЛАДАЧА
}

\author{
O. I. Novitska, S. I. Hnatyshyn \\ I. Horbachevsky Ternopil National Medical University \\ STUDY OF THE TOPIC “PEOPLE AND THINGS AROUND US” AT THE \\ CLASSES IN UKRAINIAN AS A FOREIGN LANGUAGE: METHODICAL \\ INSTRUCTIONS FOR A TEACHER
}

\begin{abstract}
Анотація. У статті представлено методичну розробку заняття з української мови як іноземної для викладачів закладів вищої освіти. Розглядаються 4 етапи практичного заняття, що сприяли розвитку живого, спонтанного мовлення студентів, розвитку уваги та когнітивного мислення, що дозволили закріпити необхідний лексичний мінімум, повторити пройдений синтаксичний і граматичний матеріал тощо. Мовне наповнення навчально-тренувальних вправ підпорядковане комунікативному підходу до навчання, який визначив наявність на занятті завдань, призначених для формування та розвитку різних видів мовленнєвої діяльності - слухання, говоріння, читання та письма.

Сприйняття і розуміння нового матеріалу підсилювалося тим, що комплексно задіяно зорову (відеосупровід і роздатковий матеріал), слухову (пояснення викладача) і механічну пам’ять (запис студентами слів і словосполучень у зошити). Робота 3 текстом $€$ важливою не лише для застосування на практиці граматичних знань, формування правильної вимови чи наголошування слів, а й для ознайомлення іноземних студентів із українською культурою, її традиціями і виховання в них поваги до нашої нації і держави.

Знання лексики, вміння будувати монологічні висловлювання, ініціювати й вести діалог-розпитування на запропоновану тему, навички узгоджувати прикметники, особові та присвійні займенники з іменниками у роді, числі й відмінку дозволять забезпечити реалізацію комунікативних потреб іноземних студентів у різних сферах спілкування: побутовій, соціальнокультурній, офіційно-діловій, навчально-професійній.

Професійне спрямування вивчення цієї теми полягає у формуванні українськомовної фахової компетентності майбутнього спеціаліста, здатного брати участь у діалоговій комунікації, розв’язувати комунікативні завдання у сфері професійної діяльності.

Розроблена система вправ відповідає програмі навчальної дисципліни «Українська мова як іноземна» для студентів спеціальності 222 «Медицина».
\end{abstract}

Ключові слова: українська мова як іноземна; методична розробка; вивчення; знання; комунікація; речі.

Abstract. The article presents the methodical instructions for the classes in Ukrainian as a foreign language for teachers of higher educational institutions. 4 stages of practical training are considered, which promoted the development of fluent, spontaneous speech of students, development of attention and cognitive thinking, allowed to fix the necessary lexical minimum, to repeat the learnt syntactic and grammatical material, etc. The language content of educational and training exercises is subject to a communicative approach to learning, which determined the presence in the classroom of tasks designed for the formation and development of various types of speech activities i.e. listening, speaking, reading and writing.

Perception and understanding of the new material was enhanced by the fact that it was comprehensively involved visual (video and handouts), auditory (teacher's explanation) and mechanical memory (students write words and phrases in the notebooks). The work with the text is important not only for the application of grammatical knowledge in practice, the formation of correct pronunciation or stress of words, but also for acquainting foreign students with Ukrainian culture, its traditions and instilling their respect for our nation and state.

Knowledge of vocabulary that serves the everyday sphere of communication on the topic of housing, its arrangement and operation, the ability to build monologues, initiate and conduct dialogue-questioning on the proposed topic, skills to match adjectives, personal and possessive pronouns with nouns in the genus, number and case will provide realization of communicative needs of foreign students in various spheres of communication: household, social cultural, business official, educational professional.

The professional direction of studying this topic is to form the Ukrainian-language professional competence of the future specialist, who will be able to participate in dialogic communication, to solve communicative tasks in the field of professional activity.

The developed system of exercises corresponds to the curriculum of the discipline "Ukrainian as a foreign language" for students

(c) О. І. Новіцька, С. І. Гнатишин 
majoring in 222 “Medicine”.

Key words: Ukrainian language as a foreign language; methodical instructions; study; knowledge; communication; room.

Вступ. Вивчення української мови як іноземної у закладах вищої освіти потребує належної уваги, тому кількість питань із часом лише розширюється. Для навчання української мови головними $€$ положення про мову як засіб спілкування, про мовлення, що складається зі звуків, слів, словосполучень та речень.

Оволодіння мовою - тривалий, трудомісткий, а головне, індивідуальний процес. У програму вивчення української мови, як й інших іноземних, входить поглиблене вивчення фонетики, граматики та лексичного складу мови, проте теоретичне вивчення поступається своїм місцем виробленню практичних навичок. Головним стає функціональний принцип навчання. Необхідно навчити студентів не тільки основ іноземної мови, а й з цікавістю та ентузіазмом спілкуватися іноземною мовою, як на професійні теми, так і в ситуаціях повсякденного життя. Іноземні студенти повинні розуміти мову, а також правильно будувати своє повідомлення у відповідь, яке має відповідати культурі співрозмовника.

Практичні заняття з української мови як іноземної - складна, цілісна, динамічна система змісту навчального матеріалу й організації роботи з ним [5, с. 196]. Викладачі української мови, працюючи 3 іноземними громадянами, постійно шукають шляхи, нові ефективні підходи до навчання іноземних студентів, за допомогою яких можна активізувати пізнавальну діяльність, активність та свідомість у засвоєнні знань, сприяти розвитку мисленнєвої діяльності.

Вправи повинні творити єдину систему з її постійними та змінними параметрами. До перших належать: врахування поетапності формування мовленнєвої компетенції, наявність цілої серії вправ, чітка послідовність їх виконання. Серед змінних параметрів - характер мовленнєвих операцій, етап навчання, види комунікативної діяльності, дозування та циклічність навчального матеріалу [1, с. 68].

Аналіз основних понять, пов’ язаних із питанням практичного викладання української мови як іноземної, концептуальні засади створення навчальнометодичних комплексів, їхню структуру та зміст виклали у своїх працях Л. Бєй, О. Тростинська, Н. Ушакова, Л. Васецька, Г. Іванишин, У. Соловій, І. Левенок, Ж. Рагріна, Л. Субота.
Мета статті - запропонувати методичну розробку для викладача до теми «Люди і речі навколо нас», апробовану на практичних заняттях з української мови як іноземної автором цієї праці.

\section{Теоретична частина.}

Тема заняття. Люди і речі навколо нас.

Мета: засвоїти лексичні одиниці на позначення осіб і речей; уміти ідентифікувати іменники в тексті, визначати їх рід і число, відповідати на питання хто це? що це?; засвоїти базові моделі вживання особових і присвійних займенників; розвивати навички читання вголос тексту на актуальну тему, дотримуючись орфоепічних та інтонаційних норм; сприяти розвитку мовлення студентів, логічного мислення, уваги, пам’яті, інтересу до вивчення мови; виховувати любов до української мови.

\section{Студент повинен знати:}

1. Лексику на позначення осіб і речей.

2. Базові моделі вживання особових та присвійних займенників.

3. Однину і множину іменника.

4. Правила побудови словосполучень, речень, запитань, відповідей на запитання.

\section{Студент повинен вміти:}

1. Ідентифікувати іменники в тексті, визначати їх рід і число, відповідати на питання хто це? що це?

2. Читати вголос текст на дану тему, дотримуючись орфоепічних та інтонаційних норм.

3. Ініціювати та вести діалог-розпитування на тему.

4. Будувати речення на запропоновану тему.

5. Відтворювати усно і писати текст теми.

6. Відповідати на запитання викладача.

7. Виконувати додаткові завдання, читати вправи.

8. Слухати і повторювати за викладачем звуки, слова, фрази.

9. Використовувати вивчену лексику у мовленні.

Перелік основних питань, які розглядаються на занятті:

1. Засвоєння лексико-граматичного матеріалу до теми «Люди і речі навколо нас».

2. Вживання займенників.

3. Вживання іменників в однині і множині.

4. Діалог-розпитування на запропоновану тему.

5. Робота з текстом.

Методика виконання практичної роботи.

Робота 1. Засвоєння лексико-граматичного матеріалу до теми. 
Завдання 1. Слухайте. Повторюйте. Читайте. Пишіть.

Викладач, студент, студентка, дівчина, хлопець, діти, сім'я, жінка, чоловік, декан, ректор, лікар, медсестра, мама, тато, дідусь, бабуся, друг, подруга, університет, деканат, факультет, курс, група, дім, гуртожиток, кімната, класна кімната, аудиторія, стіл, парта, стілець, дошка, вікно, двері, шафа, книжка, зошит, ручка, олівець, око, словник, гумка, машина, фото.

Завдання 2. Перегляд презентації до заняття.

Завдання 3. Читайте. Пишіть.

1. Це Тетяна? Так, це Тетяна.

2. Вона студентка? Так, вона студентка.

3. Це Василь? Так, це Василь.

4. Він студент? Так, він студент.

5. Це Тетяна і Василь? Так, це Тетяна і Василь.

6. Вони студенти? Так, вони студенти.

Завдання 4. Читайте діалоги.

1. - Хто це? Це викладач?

- Так, це викладач.

- Це він?

- Так, це він.

2. - Це студент?

- Так, це студент.

- Це він?

- Так, це він.

3. - Це викладач і студент?

- Так, це викладач і студент.

- Це вони?

- Так, це вони.

Робота 2. Засвоєння граматичного матеріалу.

Завдання 1. Прочитайте та запам'ятайте таблицю.

\begin{tabular}{|c|c|c|c|}
\hline \multicolumn{2}{|r|}{ Однина } & \multicolumn{2}{|c|}{ Множина } \\
\hline Вiн & $\begin{array}{l}\text { студент } \\
\text { ректор } \\
\text { гуртожиток } \\
\text { лікар } \\
\text { викладач } \\
\text { олівець } \\
\text { іноземець } \\
\text { друг } \\
\text { ученьь } \\
\text { деннь }\end{array}$ & $\begin{array}{l}\text { студенти } \\
\text { ректори } \\
\text { гуртожитки } \\
\text { лікарі } \\
\text { викладачі } \\
\text { олівці } \\
\text { іноземці } \\
\text { друзазі } \\
\text { учні } \\
\text { дні }\end{array}$ & $\Xi$ \\
\hline Вона & $\begin{array}{l}\text { книжка } \\
\text { кімната } \\
\text { бабуся } \\
\text { аудиторія } \\
\text { дівчина }\end{array}$ & $\begin{array}{l}\text { книжки } \\
\text { кімнати } \\
\text { бабусі } \\
\text { аудиторії } \\
\text { дівчата } \\
\end{array}$ & 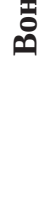 \\
\hline Воно & $\begin{array}{l}\text { вікно } \\
\text { місто } \\
\text { місце } \\
\text { море } \\
\text { завдання } \\
\text { заняття }\end{array}$ & \begin{tabular}{|l} 
вікна \\
міста \\
місця \\
моря \\
завдання \\
заняття \\
\end{tabular} & \\
\hline
\end{tabular}

Робота 3. Виконання тренувальних вправ.

Завдання 1. Розгляньте малюнки. Назвіть: 1 . Хто зображений на малюнку? 2. Що зображено на малюнку? (малюнки додаються).

Завдання 2. Напишіть слова у дві колонки.

$\begin{array}{cc}\text { Зразок. Хто? } & \text { Що? } \\ \text { викладач } & \text { кімната }\end{array}$

Словник, кімната, друг, діти, жінка, дошка, книжка, університет, деканат, декан, факультет, курс, група, дім, гуртожиток, викладач, лікар, бабуся, шафа, стілець, група, двері.

Завдання 3. Поставте запитання до підкреслених слів.

Зразок. Хто це? Це студент.

Що це? Це ручка.

1. Це фото. 2. Це декан. 3. Це вікно. 4. Це дівчина. 5. Це книжки. 6. Це шафа. 7. Це хлопець. 8. Це викладач. 9. Це двері. 10. Це олівець. 11. Це кімната. 12. Це дідусь. 13. Це ректор. 14. Це батьки.

Завдання 4. Заповніть таблицю.

\begin{tabular}{|c|c|c|}
\hline він & вона & воно \\
\hline & & \\
\hline
\end{tabular}

Довідка: жінка, чоловік, декан, ректор, діти, лікар, медсестра, мама, тато, дідусь, бабуся, Оксана, Василь, кімната, аудиторія, стіл, парта, стілець, дошка, вікно, шафа, група, книжка, зошит, ручка, олівець, око, словник, гумка, машина, фото.

Завдання 5. Читайте. Запишіть слова у формі множини.

Зразок. Студент - студенти.

Жінка, декан, лікар, медсестра, мама, учень, бабуся, кімната, аудиторія, парта, дошка, вікно, шафа, група, око, книжка, стіл, зошит, ручка, словник, гумка, машина, університет, факультет, сумка, олівець, дівчина, іноземець, завдання, перерва, лабораторія, карта, місце, день.

Робота 4. Робота з текстом.

Завдання 1. Читайте текст. Авдиторія

Ось авдиторія. Праворуч двері, ліворуч шафа. А тут столи та стільці. На столах лежать речі студентів: зошити, книги, словники, ручки, олівці. Прямо дошка. Це викладач Ігор Романович і студенти Войцех, Алі, Санчаїта, Джон, Айша та Ахмед. Вони студенти Тернопільського національного медичного університету імені І. Я. Горбачевського. Студенти-іноземці вивчають українську мову.

Завдання 2. Відповідайте на запитання.

1. Де авдиторія? 2. Що є в авдиторії? 3. Де лежать речі студентів? 4. Де навчаються студенти? 5. Де знаходиться дошка? 6. Хто Ігор Романович? 7. Як звати студентів? 8. Де навчаються студенти? 9. Що 
вивчають студенти?

Робота 5. Поточний контроль, що передбачає стандартизований метод контролю знань - письмове тестування. Студентам пропонується 12-24 тестових завдання (2-4 варіанти) з вибором однієї правильної відповіді.

Організаційна структура заняття.

1.1. Організаційна частина -5 хв.

1.2. Інструктаж студентів і розподіл груп для практичної роботи - 5 хв.

1.3. Практична робота студентів - 20 хв.

1.4. Семінарське обговорення теоретичних питань і практичної роботи - 40 хв.

1.5. Перевірка вихідного рівня знань (проводиться у вигляді тестування з кожної теми, розв’язування ситуаційних задач, відповідей на контрольні питання) - 20 хв.

Технічні засоби і методи навчання:

1. Технічні засоби та матеріальне забезпечення заняття: посібники, словники, комп'ютери, відеосистема.

2. Презентація до заняття.

3. Словесні методи - розповідь, пояснення, бесіда.

4. Асоціативний метод і мовленнєва зарядка.

5. Ілюстративний метод.

6. Проблемні запитання.

7. Тестові матеріали.

Висновки та перспективи подальших досліджень. Вивчений матеріал сприятиме адаптації студентів-іноземців до життя й навчання в умовах

\section{Список літератури}

1. Копилова I. М. Розробка системи вправ для формування професійно спрямованої компетенції в говорінні іноземною мовою / I. М. Копилова // Науковий огляд. Соціум. Наука. Культура. Філологічні науки. - Режим доступу : http://intkonf.org/kopilova-im-rozrobka-sistemivprav-dlya-formuvannya-profesiyno-spryamovanoyikompetentsiyi-v-govorinni-inozemnoyu-movoyu.

2. Мельничук I. М. Використання інтерактивних технологій у підготовці іноземних студентів до професійної діалогічної взаємодії / I. М. Мельничук // Гуманітарний вісник ДВНЗ «Переяслав-Хмельницький державний педагогічний університет імені Григорія Сковороди». 2016. - Вип. 36, т. VII. - С. 393-402.

3. Новіцька О. I. Реалізація інноваційних методів навчання на практичних заняттях з української мови як іноземної / О. І. Новіцька // Зб. наук. праць Херсонського українськомовного середовища.

Професійне спрямування вивчення цієї теми полягає у формуванні українськомовної фахової компетентності майбутнього спеціаліста, здатного брати участь у діалоговій комунікації, розв’язувати комунікативні завдання у сфері професійної діяльності.

Принципи планування і проведення практичних занять з української мови як іноземної залежать від багатьох чинників. Проте добір засобів і методів навчання диктується контингентом студентів і їх потребами - чи це слухачі підготовчого відділення, які володіють українською мовою на початковому рівні, чи це іноземці, які щойно прибули в Тернопіль і лише розпочинають знайомство з Україною й українським словом.

Ключовою проблемою вивчення цієї теми, як і викладання української мови як іноземної загалом, $€$ формування мотивації студентів до їі навчання. Оскільки у ТНМУ імені І. Я. Горбачевського всі навчальні дисципліни, за винятком української мови, для іноземних студентів викладають англійською мовою, більшість першокурсників не усвідомлює доцільності вивчати українську мову. I лише завдяки професійній майстерності викладача, його творчому підходу до навчання, використанню інтерактивних методів вдається формувати у студентів позитивні мотиви до навчання і досягати всіх цілей навчального процесу: освітньої, практичної, розвивальної, виховної.

державного університету. Серія «Педагогічні науки». 2016. - Вип. LXXIV, т. 3. - C. 77-81.

4. Робоча програма 3 дисципліни «Українська мова як іноземна» для студентів спеціальності 222 «Медицина» / [уклад. О. Новіцька, Л. Шеремета]. - Режим доступу : https://moodle.tdmu.edu.ua/mod/resource/view. php?id=230438.

5. Стефанишин К. Л. Вивчення теми «Кольори. Одяг. Взуття» на заняттях з української мови як іноземної : методична розробка практичного заняття для викладача / К. Л. Стефанишин // Науковий часопис НПУ імені М. П. Драгоманова. Педагогічні науки: реалії та перспективи. - 2019. - Вип. 68. - С. 196-200.

6. Українська мова як іноземна : навч. посіб. / [I. І. Гаврищак, І. Д. Драч, В. І. Зевако та ін.] ; за ред. М. П. Тишковець. - Тернопіль : ТНМУ, 2019. - 168 с. 


\section{References}

1. Kopylova, I. (2018). Rozrobka systemy vprav dlia formuvannia profesiino spriamovanoi kompetentsii $\mathrm{v}$ hovorinni inozemnoiu movoiu [Development of a system of exercises for the formation of professionally oriented competence in speaking a foreign language]. Naukovyi ohliad. Sotsium. Nauka. Kultura. Filolohichni nauky Scientific review. Society. Science. Culture. Philological sciences. Retrieved from: http://intkonf.org/kopilova-imrozrobka-sistemi-vprav-dlya-formuvannya-profesiynospryamovanoyi-kompetentsiyi-v-govorinni-inozemnoyumovoyu [in Ukrainian].

2. Melnychuk, I. (2016). Vykorystannia interaktyvnykh tekhnolohii u pidhotovtsi inozemnykh studentiv do profesiinoi dialohichnoi vzaiemodii [The use of interactive technologies in preparing foreign students for professional dialogic interaction]. Humanitarnyi visnyk - Humanitarian Bulletin, 36, 393-402 [in Ukrainian].

3. Novitska, O.I. (2016). Realizatsiya innovatsiynykh metodiv navchannya na praktychnykh zanyattyakh z ukrayins'koyi movy yak inozemnoyi [Realization of innovative teaching methods in practical classes on the Ukrainian language as a foreign language]. $\mathrm{Zb}$. nauk. prats Khersonskoho derzhavnoho universytetu. Seriya «Pedahohichni nauky»-Coll. Science. Proceedings of Kherson State University. Series "Pedagogical Sciences", LXXIV(3), 77-81 [in Ukrainian].

4. Novitska, O., \& Sheremeta, L. Robocha prohrama z dystsypliny «Ukrainska mova yak inozemna» dlia studentiv spetsialnosti 222 «Medytsyna» [Work program on the subject "Ukrainian as a foreign language" for students majoring in 222 "Medicine”]. Retrieved from: https://moodle.tdmu. edu.ua/mod/resource/view.php?id=230438 [in Ukrainian].

5. Stefanyshyn, K. (2019). Vyvchennia temy «Kolory. Odiah. Vzuttia» na zaniattiakh z ukrainskoi movy yak inozemnoi: metodychna rozrobka praktychnoho zaniattia dlia vykladacha [Studying the topic "Colors. Clothes. Footwear" in classes on Ukrainian as a foreign language: methodical development of a practical lesson for a teacher]. Pedahohichni nauky: realii ta perspektyvy - Pedagogical Sciences: Realities and Prospects, 68, 196-200 [in Ukrainian].

6. Havryshcak, I.I., Drach, I.D., Zevako, V.I., \& Novitska, O.I. (2019). Ukrainska mova yak inozemna [Ukrainian as a foreign language]. Ternopil: TNMU [in Ukrainian]. 